\title{
Government spending multipliers in contraction and expansion
}

Walid Qazizada and Engelbert Stockhammer

1 May 2014

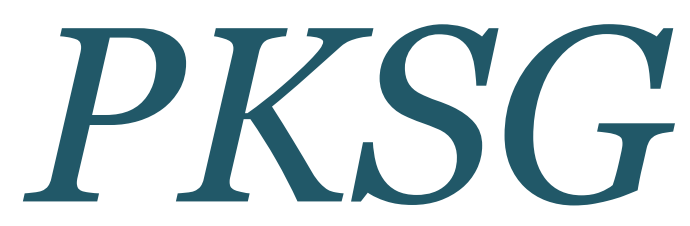

Post Keynesian Economics Study Group

Working Paper 1404

This paper may be downloaded free of charge from www.postkeynesian.net

2014 ㄷ Engelbert Stockhammer

Users may download and/or print one copy to facilitate their private study or for non-commercial research and may forward the link to others for similar purposes. Users may not engage in further distribution of this material or use it for any profit-making activities or any other form of commercial gain. 


\title{
Government spending multipliers in contraction and expansion
}

\begin{abstract}
This paper investigates the impact of government spending on output and the size of the spending multiplier during periods of output contraction vs. expansion. It also investigates the impact of spending when the economy hits the nominal zero lower bound. It uses a panel of 21 advanced countries over the period of 1979-2011, applying a TSLS estimation technique. We find a spending multiplier of close to 1 during expansion and values of up to 3 during contractions. However, our results do not indicate a difference in the impact of spending during nominal zero lower bound periods.
\end{abstract}

Keywords: fiscal multiplier, fiscal policy, panel analysis, output contraction

JEL classifications: E62, C36

Acknowledgements. An earlier version of the paper was presented at the Research Seminar at Kingston University. The authors have benefited from comments by Ozlem Onaran, LouisPhilippe Rochon, Chris Stewart and Achim Truger. The usual disclaimers apply.

\section{Engelbert Stockhammer}

Kingston University

Engelbert Stockhammer, Kingston University, School of Economics, History and Politics, Penrhyn Road, Kingston upon Thames, KT1 2EE, UK

Email: e.stockhammer@kingston.ac.uk 


\section{Government spending multipliers in contraction and expansion}

\section{Introduction}

The financial crisis that began in 2007 has brought an old question of macroeconomics to the forefront again: What should fiscal policy do in a recession? Should it counteract swings in private demand, accepting higher budget deficits, or should it aim at sustainable public balances? The answer to these questions depends among other things on how large the fiscal multiplier is.

This question already figured prominently in the debates between Keynesians and Monetarists in the 1960s. With the renaissance of New Classical economics in the 1970s and 80 s the role of fiscal policy became downplayed. The Ricardian equivalence theorem argued that anticipated fiscal expansions would be ineffective because people expect future tax increases (Barro, 1989a). The New Keynesian reply to this was that a part of the population will be credit constraint and will react to current income rather than permanent income (Mankiw, 2000). Empirically the majority of studies did show non-zero multipliers (Hemming et al 2002; Bouthevillain et al. 2009). With Giavazzi and Pagano (1990) the New Classical argument moved to the empirical terrain and provided a powerful new term ‘expansionary fiscal contractions’ (EFC).

Prior to the crisis the majority views in macroeconomics, the so-called New Consensus Model (Woodford 2009), assigned only a minor role to fiscal policy, which is essentially reduced to automatic stabilisers. However, with the deep recession following 2007, this view has been put into question. The IMF has highlighted that existing macro models consistently underestimated fiscal multipliers (Blanchard and Leigh 2013). Also, the validity of EFC has been questioned (Guardjardo et al 2011). Recently, several papers of Keynesian inspiration have argued that multipliers will be different during a crisis from those of normal times. For 
example, de Long and Summers (2012) argue that in a depressed economy "the Keynesian multiplier is likely to be substantially greater than the relatively small value it is thought to have in normal times" (de Long and Summers 2012, 233f).

There is a large empirical literature estimating fiscal multipliers econometrically. Recent estimation strategies fall into three broad groups. The first group utilises New Keynesian Dynamic Stochastic General Equilibrium (NK DSGE) models. These models are theoryguided and impose strong long-run restrictions. The second group uses VAR models that estimate a system of equations with an attempt to separate the innovations in fiscal shocks. The third group consists of panel analyses that typically impose no long term restrictions. The vast majority of studies estimate multipliers that are invariant with respect to the state of the economy. Only very recently have there been attempts to provide estimates of the multiplier that differ during boom and downswing. Christiano et al. (2011) do so in a NK DSGE model. Auerbach and Gorodnichenko (2012), De Cos and Moral-Benito (2013) and Thomakos (2012) use a VAR approach for the USA, Spain and Greece respectively distinguishing between recession and non-recession periods. Afonso et al. (2010) and Turini et al. (2012) use a panel two stage least square (TSLS) approach for large panels of advanced and developing economies.

This paper contributes to the debate by estimating fiscal multipliers for a panel of 21 OECD countries (1979-2011) and allow the multiplier to differ in the expansion and the contraction of the growth cycle. ${ }^{1}$ We use government final consumption expenditures and total government expenditures as measures of fiscal activity. In variation of the basic

\footnotetext{
${ }^{1}$ The term 'recession' is used widely in the relevant literature, but potentially confusing. Auerbach and Gorodnichenko (2012) and Thomakos (2012) define as recessions the periods with a negative output gap. De Cos and Moral - Benito (2013) define recessionary periods based on output gap, change in unemployment rate, banking defaults, following Reinhart and Rogoff (2010), and periods of fiscal stress with large deficit to GDP ratio and debt to GDP ratio. However, recessions are sometimes defined as periods of at least two consecutive quarters of negative GDP growth. We will use a dataset identifying the turning points of the growth cycle. We prefer the term 'downswing' rather than recession.
} 
specifications we also allow the multiplier to vary if the economy has hit the zero lower interest bound (ZLB). We use a two stage least squares (TSLS) procedure to address the issue of endogeneity. We find that TSLS estimates give multipliers substantially above those of OLS estimates. The TSLS gives multipliers of unity for expansionary times and above 3 during contractionary periods.

The paper is structured as follows. Section 2 reviews the debate on fiscal policy and section 3 discusses the econometric literature on fiscal multipliers. Section 4 presents the estimation strategy and data definitions and sources. Section 5 gives the empirical results and section 6 concludes.

\section{The debate on fiscal policy}

In traditional Keynesian theory, deficit-financed government spending was regarded as the main stabilization tool, at least in the short-run. The spending multiplier was considered as a function of the marginal propensity to consume, the marginal propensity to import and the tax propensities. The estimated multipliers were high (e.g. Evans 1969). Monetarism challenged Keynesian theory in the 1960 s and 70s. It argued that consumption expenditures would depend on permanent rather than current income. Furthermore, government deficits would increase interest rates, which crowds out private investment. Eventually, the economy would always return to the natural rate of unemployment and accumulate a high level of debt (Friedman, 1968). Consequently, fiscal multipliers were likely to be low, but non-trivial in the short-run.

New Classical economics went further in its criticism of the multiplier based on the assumptions of rational expectations and continuous market clearing (Laidler, 1986). The Ricardian equivalence theorem demonstrated that government spending financed by issuing 
bonds would be ineffective because rational agents would expect future tax rise and would consequently reduce their consumption and increase savings to pay out higher taxes in the future (Barro, 1989a). In contrast to Keynesian theory, expansionary fiscal policy would have contractionary rather than expansionary effects on private consumption.

New Classical models were developed further into real business cycle (RBC) theory and DSGE models. RBC is a stochastic version of neoclassical theory with infinitely lived intertemporal optimizing agents (Barro, 1989b). Since this model is built on strict neoclassical assumptions, the Ricardian equivalence theorem applies. The impact of spending on output is less than one if tax financed, and negative or zero if deficit financed. Also, because of its negative wealth effect, government spending dampens private consumption.

In response, New Keynesian theory demonstrated that rational behavior and expectations are consistent with market failures and price and wage rigidities, if there are transaction costs, market power or asymmetric information (Greenwald and Stiglitz, 1987). They argued that the Ricardian equivalence implicitly assumed perfect capital markets. If, however, some individuals were finance-constrained, their consumption expenditures may respond to current income. New Keynesian models now typically assume the existence of a share of rational ('Ricardian') consumers as well as a share of rule-of-thumb consumers (Mankiw, 2000). Government spending increases income of these consumers, their consumption and consequently aggregate output. Thus New Keynesians reestablished a (potential) for fiscal policy.

In the late 1990s and early 2000 New Keynesian price and wage rigidities were introduced into DSGE models and have been widely used in policy analysis. This strand of the literature is referred to as New Synthesis or NK-DSGE (Woodford, 2009). Inclusion of rule-of-thumb consumers and sticky prices in the model makes the impact of government spending positive and large (Gali et. al, 2007). Following a spending shock, price stickiness increases real 
wages which increases the income of rule-of-thumb consumers, who will their expenditures and therefore aggregate demand. The impact of the spending shock is not long lasting because the model is mainly built on neoclassical foundations. Furthermore, with a central bank following a Taylor-rule reaction function, which is the standard assumption for policy analysis, the size of multiplier in these models is smaller than traditional Keynesian multipliers.

Giavazzi and Pagano (1990) took the argument even further and coined the term "expansionary fiscal contraction". Investigating the effect of an expansion in the cyclically adjusted primary balance (CAPB) in Denmark and Ireland during 1980s they found a positive correlation with economic growth and private consumption. Therefore, they argued that a large and persistent reduction in government spending will have an expansionary impact on private consumption and ultimately GDP. This effect prevails when agents expect a further reduction in government spending and taxation because of a sharp reduction in government spending. In contrast, Guajarado et al. (2011) claim that the expansionary effect of fiscal consolidation is overstated. Changes in CAPB as a measure of fiscal balance leads to biased results in favour of expansionary fiscal contraction, because they can be an outcome of nonpolicy changes and correlated with other developments such as a boom in stock market.

The global financial crisis of 2007 brought the question of expansionary deficit spending back to the forefront. At the onset of the crisis, most countries embarked on a widespread use of fiscal stimulus. Khatiwada (2009) provides a comprehensive account of fiscal response by 32 countries after the global financial crisis. However, in many countries, namely in Europe, fiscal policy adopted a much more restrictive stance. The ongoing political debates on austerity (Blyth, 2013) are reflected in an intense academic debate and have led to a restatement of Keynesian arguments. 
The key argument in this is that in a recession with high unemployment, prices may fall. As the interest rate is at its zero-lower bound (ZLB), this makes monetary policy ineffective as the central bank loses its ability to lower interest rates further. In NK-DSGE, when nominal interest rates are stuck at zero, real interest rates rise, which then leads to a deflationary spiral. An increase in government spending counteracts the deflationary spiral and drives down the real interest and causes a large increase in output (Christiano et al., 2011). Michaillat (2012) claims that fiscal policy is also more effective not only at the zero lower bound, but also when the labour market is depressed. The higher the unemployment in the private sector, the more effective is expansionary spending when financed by labour tax, which will then increase public employment. Turini et al. (2012) argue that the underlying reason for the greater impact of fiscal policy during the banking crisis is the presence of not only rule-of-thumb consumers, but also households whose borrowing is constrained by the value of their collateral. Eggertson and Krugman (2012) show that a NK-DSGE model with households with different rates of time preference can generate strong Keynesian features if finance constraints become binding. Fiscal policy alleviates these constraints and leaves a greater impact on output. De Long and Summers (2012) go further by positing hysteresis effects and thus also find positive long run effects of fiscal policy.

There is a profound and long-standing disagreement about the size of multipliers in economic theory. It will depend on numerous assumptions: including the conduct of monetary policy, nominal and real rigidities, whether consumers are Ricardian or follow a rule-of-thumb approach, the size of the marginal propensity to consume and the marginal propensity to import and etc. In the aftermath of the 2007 crisis several contributions have highlighted the possibility that the multiplier may vary with economic conditions. It may be substantially higher in times of recessions with underutilized capacity. Substantial parts of modern mainstream macroeconomics assign a privileged role to monetary policy in short- 
term stabilization. In this context, New Keynesians emphasized that once inflation rates get close to zero (the famous ZLB) the ability of monetary policy to set the interest rate is limited. According to this view one would expect periods where the ZLB is binding to be the one where the multiplier takes different values.

\section{A review of recent empirical studies}

There is a large literature exploring the multiplier effect of spending on output econometrically. It can broadly be grouped into studies using a vector autoregression (VAR), NK-DSGE models and single equation estimation techniques (OLS, GMM and TSLS estimations). The VAR approach is an empirically driven systems approach, typically estimating up to five equations. Some of them also impose long-run restrictions. NK-DSGE models are large theory-guided models that impose many theoretically motivated restrictions. Usually these involve various forms of rational behaviour and monetary policy following a Taylor rule. Single equation estimations are the simplest that either use independent proxies for government expenditures (such as military spending) or use two-stage procedures or GMM to counter endogeneity. Recently, panel data have been used extensively within this approach. The overwhelming majority of studies in all three approaches implicitly assume a linear multiplier effect and only in the last few years has there been systematic research on nonlinear effects of government spending. Table 1 gives a summary of key papers in this literature. Gechert and Will (2012), Hebous (2011) and Spilimbergo et al (2009) provide more comprehensive reviews.

Table 1 about here 
The VAR technique involves estimating a system of equations with an attempt to separate the innovations in government spending shocks and the response of GDP and other concerned variables. The precise magnitude of the multiplier hinges on the approach to identification of fiscal shocks and the sample under study. Caldara and Kamps (2008) provide a comprehensive technical discussion and comparison of different approaches. In structural VAR (SVAR) and Recursive VAR (RVAR), a multiplier larger than unity has been reported for the US (see for example, Blanchard and Perotti 2002; Gali et al. 2007; Fatas and Mihov 2001). However, Perotti (2005) claims that a multiplier greater than unity can only be found in pre-1980s in the US, and it is smaller than multipliers found in four other OECD countries during 1960-2001. Burriel et al. (2010) argue that multipliers are smaller than one in the US and EMU countries. However, they also show that the size of multipliers changes considerably once they control for the financial stress and government debt-to-GDP ratio.

For a sample of 44 countries, Ilzetzki et al. (2013) argue that the spending multiplier for government consumption is less than one and it is larger than unity for government investment. They also claim that the impact of spending shocks diminishes with high levels of debt, flexible exchange rate regimes, and greater openness. However, Gechert and Mentges (2013) show that the omission of financial variables can create a substantive downward bias in the estimation of spending multipliers. All the aforementioned VAR studies consistently report a positive response of private consumption, following a government spending shock. Therefore, there is clear evidence of new Keynesian rule-ofthumb consumers and Keynesian multipliers, at least in case of the US.

Other VAR studies show a small and short-lived positive or negative response of output and private consumption following spending shocks. For example, Mountford and Uhlig (2005) with a sign restriction approach (MH-VAR) indicate a short-term spending multiplier of 0.65 and -0.97 at the end of the period for the US and do not show a significant movement 
of private consumption. Ramey and Shapiro (1999) in an event study approach (EV-VAR) claim that private consumption responds negatively even though output increases for three quarters in the US. Their results support RBC theory and Ricardian equivalence, but in a similar approach, Burnside et al. (2004) find a small movement in private consumption and a short-lived rise in private investment.

Compared to VAR studies, calibrated NK-DSGE model-based studies impose more theoretically motivated restrictions on the system. These restrictions are in the form of a monetary policy following a Taylor rule and the inclusion of Ricardian consumers. Forni et al. (2009) utilize a NK - DSGE model for Euro Area for the period 1980-2005 and report that public expenditures have a mild Keynesian effect on output. Their findings reveal that the biggest impact comes from the transfer to households, accounting for a one-to-one increase in disposable income of non- Ricardian consumers. Similarly, Afonso and Ricardo (2012) also use a calibrated NK - DSGE model for the US, the UK, Germany and Italy for the period of 1964 to 2007 and they show a small impact on output following a fiscal shock.

Ratto et al. (2009), also using a calibrated NK-DSGE model, study the impact of spending shocks on output in the Euro Area for the period of 1981 to 2006 . They find that government consumption shocks crowd-out private investment and private consumption of Ricardian consumers, but crowd-in private consumption of non-Ricardian consumers. However, because of a lump-sum increase in taxes, liquidity constrained consumers also cut back their consumption in the medium-term. Overall, the aggregate private consumption response was found to be negative. In terms of multipliers, a 1 per cent increase in spending increases GDP by 0.73 in the first quarter falling to 0.45 in the fourth quarter. Overall, NK-DSGE models typically yield a small or negative impact of public spending on output due to the assumption of Ricardian households and monetary policy following a Taylor-rule. 
Other studies of spending multipliers use a single-equation estimation approach. Compared to the VAR approach, these studies do not involve estimating a system of equations and, compared to NK-DSGE approach, they do not impose theoretical restrictions. To overcome the endogeneity of fiscal spending, they use different approaches. For instance, in order to study the impact of spending in 15 EU member countries, Afonso and Fuceri (2010) use a cross-sectional time-series OLS regression using a five-year period, from 1970-2004. They find that governments' transfers, consumption and investment have a negative and statistically significant effect on growth. Afonso and Alegre (2011) estimate an endogenous growth model with a GMM estimator for 15 EU member countries during 1971-2006. They find a positive impact of government investment and budget deficit and negative impact of government consumption. On the other hand, for Italy, Acconcia et al. (2011) reports spending multiplier of 1.2-1.4 for the period of 1990-1999 using TSLS estimation. For the government spending they use a proxy, that is the large cuts in government investment enforced by law due to infiltration of mafia in a local city council. It is can be observed that the results of these studies are mixed and depend on assumption of endogeneity of fiscal spending.

In a meta-regression analysis, Gechert and Will (2012) conclude that size of multipliers depends on econometrics techniques. Assessing 89 papers with varying approaches, they show that among NK-DSGE, VAR, and Single equation the latter gives the largest multipliers.

The studies discussed so far implicitly assume a linear multiplier. There are only a few studies that allow for different effects according to economic circumstances (Parker, 2011), for instance, investigates nonlinearity during periods of normal times vs. financial crisis, recession or ZLB. Most of these studies are very recent and have not been published in peer refereed journals yet. Again, the literature falls into several groups. Within the VAR approach 
the nonlinearity of government spending has been studied using regime switching VAR (RSVAR) models. In these models, consistent with Keynesian theory, the government spending multiplier has been reported to be larger during recessions compared to normal times. For instance, for a panel of OECD countries for the period of 1985-2010, Auerbach and Gorodnichenko (2012) claim that the spending multiplier is larger during recession (periods where output gap is negative) vs. normal times. For the sample of the US, they report a multiplier of 2.3 during recession and almost near zero during normal times. De Cos and Moral-Benito (2013) studying Spain for the period of 1986 - 2012 finds a spending multiplier of 1.4 during recession and 0.6 during tranquil periods. Similarly, for Greece for the period of 2000-2012, Thomakos (2012) reports a spending multiplier of 1.32 during recessions and zero during normal times

The literature on investigating the nonlinearity of government spending in calibrated NKDSGE models is limited. However, Christiano et al. (2011) have provided an important contribution. Analyzing the impact of government spending, they claim that if monetary policy follows a Taylor-rule, the spending multiplier is less than one. However, if nominal interest rate stays constant at the binding zero-bound, the multiplier is 1.6 on impact with a peak value of 2.3 .

Recent studies have also used panel estimation to investigate nonlinearity of government spending, the imapct of spending during normal times vs. during a crisis. To overcome endogeneity, these investigations have employed TSLS estimations. However, these studies rely on very large samples of countries and when restricted to OECD countries they fail to find statistically significant results. Turini et al. (2012) in a study of 56 countries find that fiscal policy is more effective during banking crises than in normal times., They use two instrumental variables for government expenditures: an election variable referring to political budget cycle (Brender and Drazen, 2004) and lagged value of cyclically adjusted primary 
balance. For banking crises, they use the starting year of the crisis from Laeven and Valencia (2008) and complement it with Reinhart and Rogoff (2010) and other studies. Their results indicate a multiplier of 0.8 during a crisis compared to 0.2 during normal times for the whole sample, but when restricting TSLS estimation to EU and OECD countries, the results become insignificant. The validity of instruments is not reported.

Afonso et al. (2010) find that political budget cycle and lagged budget balance ratios are not statistically valid instruments for government spending in OECD countries. They study the difference between spending multipliers of crisis and normal times for a panel of 98 countries for the period 1981-2007. They also use the Laeven and Valencia (2008) dataset of financial crisis with one year and two year definition of crisis and use the lagged budget balance ratio and distance-to-election variable as instruments for government spending growth $^{2}$. Spending multipliers are larger in recession compared to normal times, but the difference is statistically insignificant. The reported regular spending multiplier ranges from 0.6 to 1.1. Moreover, when disaggregating the sample into OECD and non-OECD countries, their investigation could not find a strong instrument for government spending for OECD countries. Therefore, their results for OECD countries remained inconclusive.

The impact of government spending and the size of spending multipliers surveyed in the literature vary with sample, econometric methodology, identification of fiscal shocks, assumption regarding the type of households and state of the economy. In general, all VAR studies show a positive response of output following a government spending shock. However, only SVAR and RVAR, in line with Keynesian theory, show a positive response of private consumption. In calibrated NK-DSGE models, the size of spending multiplier is smaller than one due to the assumption of monetary policy following a Taylor-rule and Ricardian

\footnotetext{
${ }^{2}$ Afonso et al (2010) motivated by political budget cycle (Brender and Drazen, 2004) construct a variable measuring the distance between current and the next year of election, called distance to election variable and use as an instrument for government spending growth.
} 
equivalence. The results from single equation estimation approach remains mixed. As far as nonlinearity, most of the empirical works show larger multipliers during recessions compared to normal times. However, the size of multiplier still varies with econometric methodology, with multipliers more than unity only reported by SVAR technique. Recent studies use TSLS estimation and use election periods and lagged budget balance ratio as instrumental variables for government spending. These studies do not find significant results for OECD countries and instrumental variables are shown not to be statistically valid.

\section{Empirical Methodology and Data}

To assess the impact of government spending on output, we estimate the following regression equation:

$$
\begin{aligned}
& \mathrm{GDP}_{\mathrm{it}}=\mathrm{C}_{\mathrm{i}}+\beta \mathrm{GDP}_{\mathrm{it}-1}+\theta \mathrm{X}_{\mathrm{it}, \mathrm{it}-1}+\gamma \text { Cont }_{\mathrm{it}}+\varnothing \text { Spend }_{\mathrm{it}} * \text { Cont }_{\mathrm{it}}+\alpha \text { Spend }_{\mathrm{it}} * \\
& \left(1-\text { Cont }_{\mathrm{it}}\right)+\mathrm{u}_{\mathrm{it}}
\end{aligned}
$$

In equation ( 1$)$, subscript $\mathrm{i}$ denotes the country $(\mathrm{i}=1 . . \mathrm{n})$ and $\mathrm{t}$ denotes the period $(\mathrm{t}=1 \ldots \mathrm{T}) . \mathrm{C}$ is a common or individual intercept depending on specifications. GDP refers to real GDP growth rate. $\mathrm{X}_{\mathrm{it}, \mathrm{it}-1}$ is a vector of other explanatory variables, that will include population growth, catching up term, inflation, export shock, and trade. Cont ${ }_{i t}$ is a dummy variable that captures output contraction in period t for country i. $\emptyset$ Spend $_{\mathrm{it}}{ }^{*} \operatorname{Cont}_{\mathrm{it}}$ gauges the impact of spending growth during contraction and $\alpha \operatorname{Spend}_{\mathrm{it}}{ }^{*}\left(1-\right.$ Cont $\left._{\mathrm{it}}\right)$ estimates the impact of spending growth during expansion. $\mathrm{u}_{\mathrm{it}}$ is the error term and it is assumed to be independent across countries. We also investigate nonlinearity of government spending for periods of nominal zero lower bound (ZLB) by replacing Cont ${ }_{\text {it }}$ with ZLB $_{\text {it }}$. (discussed below) Our expectation is that the coefficient for the interaction term capturing spending during contractionary period will be larger than that for spending in periods of expansion. 
Reverse causation of Spend is a well-known potential problem. To overcome endogeneity we use TSLS estimation. Previous TSLS studies have used election variables and the lagged budget balance ratio as instrument for government spending (see for example, Turini et al. (2012) and Afonso et al. (2010). However, Afonso et al. (2010) report that these are not statistically valid instruments for government spending for OECD countries. This is also the case in our sample. ${ }^{3}$ Therefore, we use one year lagged spending as an instrument for spending itself. ${ }^{4}$ For the modelling of interactions, we follow Balli and Sorensen (2013). At the first stage, we estimate the auxiliary equation for government spending growth and obtain the fitted values. At the second stage, we interact the fitted values with the contraction dummy variable.

Following the literature we will use pooled TSLS and fixed effects (FE) TSLS estimators. An alternative to this would be the GMM panel estimator (e.g. Arellano and Bond 1991). These estimators are recommended for panels with small $\mathrm{T}$ and large $\mathrm{N}$. This is because as $\mathrm{T}$ increases the dynamic panel bias becomes insignificant. In addition, as $\mathrm{T}$ increases the number of GMM instruments rapidly proliferates. In our case $\mathrm{T}=32$ and $\mathrm{N}=21$. Thus we prefer the TSLS estimators. The FE estimator with lagged dependent variable will be biased and the bias is of order 1/T (see for example, Nickell, 1981). The bias arises because the lagged dependent variable can be correlated with error term. In our sample the bias is likely to be small. Kiviet (1995) reports Monte Carlo results suggesting that with long $\mathrm{T}$ and small $\mathrm{N}$, the bias is moderate; Roodman (2006) reports a bias of $20 \%$ at $\mathrm{T}=30$. The pooled TSLS estimator does not suffer from bias. We will thus routinely report both the FE TSLS and the

\footnotetext{
${ }^{3}$ Our data source differs from Afonso et al. (2010). We use mainly AMECO while Afonso et al. (2010) use the IMF Outlook database.

${ }^{4} \mathrm{We}$ also tried to instrument government spending with budget balance ratio and election period as commonly used in literature, however, neither of them individually or collectively were found to be a valid instrument.
} 
pooled TSLS estimators. Each regression will be estimated with heteroskedasticity and autocorrelation consistent (HAC) robust standard errors (Croux et al., 2003).

This study covers an unbalanced panel of 21 OECD countries over the period 1979-2011 using annual data. ${ }^{5}$ The source and definition of data is listed in Appendix A1. The Contraction dummy (Cont) is obtained from Federal Reserve Bank of St. Louis's website. It is based on the OECD composite leading indicators, defining periods of output contraction from the midpoint of the period of the peak and ending at the midpoint of the period of trough. Periods of output contraction is given value 1 and 0 otherwise. To investigate whether the multiplier changes when inflation or interest rates get close to zero rather than when the economy is in a downswing, we create several dummy variables based on inflation rate and short-term nominal interest rate obtained from AMECO. ZLB1 and ZLB2 are dummy variables that take the value of 1 in periods when the inflation rate is less than $2 \%$ and $1 \%$ respectively. ZLB3 refer to periods when the nominal interest rate is less than $1 \%$. Data on real GDP Growth rate (GDP) is taken from AMECO Database. Real government spending growth is also taken from AMECO database. We use two definitions of government spending; a narrower definition is government final consumption spending (GFC), which is spending on goods and services. The broader definition that is commonly found in the literature is total government spending (GTE), it is GFC plus government investment expenditure.

As control variables we use those suggested by growth theory and by the recent literature if they are statistically significant: Population growth rate (POP) taken from OECD database and catching up term (CAT) that is a country's GDP vis-a-vis US GDP taken from Federal Reserve Bank of St. Louis's website. We also control for inflation (INF), short term real

\footnotetext{
${ }^{5}$ The countries are Austria, Belgium, Denmark, Finland, France, Germany, Greece, Hungary, Iceland, Ireland, Italy, Japan, Netherlands, Norway, Poland, Portugal, Spain, Sweden, Switzerland, United Kingdom, and United States.
} 
interest rate (R) and export shock (Xshock) taken from AMECO. Gechert and Mentges (2013) have demonstrated that omission of financial variables will cause downward bias in estimation of spending multipliers, therefore we also control for domestic credit to private sector as ratio of GDP (DCP) taken from the World Bank database.

In the sample of 21 countries in this study, there are 293 observations for contractionary periods and 362 observations for expansionary times. On average, GDP grows $2.2 \%$ for the whole sample. However, during contraction phase of the business cycle GDP growth is $1.38 \%$ compared to $2.9 \%$ during expansionary times. In the sample, GFC as share of GDP is $21.15 \%$ and GTE as share of GDP is $24.45 \%$. GFC growth rate on average is $2.1 \%$, but during contraction it moves countercyclically to GDP growth and grows $2.2 \%$ vs. $2 \%$ during expansionary times. Similarly, GTE growth rate is $1.95 \%$ and it grows at $2 \%$ during contractionary periods compared to $1.9 \%$ during expansion.

\section{Results}

Table 2 reports the results for equation (1), considering GFC growth for government spending. Specifications 1 and 2 are pooled TSLS estimation, others are FE TSLS, FE and pooled OLS respectively. In specification (1) we only control for lagged value of GDP growth rate, population growth, and catching- up term., All other variables except for the catching-up term and GFC interaction with expansionary dummy are statistically significant at least at the $5 \%$ level or below. Periods of output contraction are highly significant and reduce GDP growth by $2.4 \%$ percentage points. Government spending during contractionary periods is also highly significant and positively affect GDP growth. On the other hand, government spending during expansionary periods is statistically insignificant and smaller than contractionary periods spending. Our coefficient estimate is an elasticity. To get the size of spending multiplier, we multiply the coefficient of interaction terms with inverse ratio of 
government spending over GDP. ${ }^{6}$ In the sample of 21 OECD countries under study, GFC as ratio of GDP is $21.15 \%$, therefore the estimated multiplier for contractionary and expansionary periods in specification 1 are 2.48 and 0.95 respectively.

Table 2 about here

Specification 2 includes additional control variables. Controlling for inflation, export shock, short-term real interest rate and domestic credit to private sector, the size of coefficients for both contractionary and expansionary periods increases, but spending during periods of output expansion still remains statistically insignificant. Gechert and Mentges (2013) show that omission of financial variable leads to downward bias in estimation of spending multipliers, therefore with inclusion of DCP, specification 2 is our preferred estimation. Spending multipliers in this specification are 3.07 and 1.01 for contractionary and expansionary times respectively. We get even larger multipliers with the fixed effects TSLS in specification 3. The Hausman test for common group intercepts suggests that FE TSLS is preferred to pooled TLS, however in FE TSLS the instrument for GFC is weak with first stage F-statistics of 8.7. Staiger and Stock (1997) suggest a first stage F-statistics of at least 10 as a rule of thumb for validity of the instrument. For comparability, we also report estimations for FE and pooled OLS without controlling endogeneity of GFC in specification 4 and 5 respectively. With respect to statistical significance, the results are similar, but the size of multiplier is substantially lower. Nonetheless, the multipliers for contractionary times still remain above 1 .

\footnotetext{
${ }^{6}$ Denoting GDP as Y, government spending as G and spending multiplier as $\mathrm{m}, \frac{Y_{t}-Y_{t-1}}{Y_{t-1}}=$ $\frac{m\left(G_{t}-G_{t-1}\right)}{G_{t}} \leftrightarrow \Delta Y_{t}=\frac{\Delta G_{t}}{\frac{Y_{t-1}}{G_{t-1}}}$ and $\frac{\Delta Y_{t}}{\Delta G_{t}} \cong m *\left(\frac{Y}{G}\right)$
} 
In terms of multipliers, our results gives strong support to the Keynesian view that spending multipliers are larger during downswings compared to periods of economic expansion. With regards to magnitude of multiplier, the contractionary periods' multipliers are close to Auerbach and Gorodnichenko (2012) findings for recessionary periods and Christiano et al. (2011) findings for ZLB. In contrast to Afonso et al. (2010), we find statistically valid instruments for the sample of OECD countries in our study. However, aforementioned studies consider a broader definition of government spending; therefore for the sake of robustness we also report the results for GTE as government spending variable in Table 3.

Table 3 about here

The results for GTE in Table 3 are qualitatively similar to those for GFC. Specification 1 reports the results for pooled TSLS estimation. The estimated multiplier is 1.97 and statistically significant for contractionary period vs. 0.48 and statistically insignificant for expansionary times. We get a slightly smaller multiplier for contractionary times (1.85) with FE TSLS estimation in specification 2 compared to 1 and larger multiplier for expansionary times. However, the instrument for GTE becomes weak. Nonetheless, comparing these results with pooled OLS and FE estimations in specification 3 and 4 we can observe that contractionary period multipliers are substantially smaller than TSLS estimation and expansionary times' spending becomes statistically significant. Overall, although the measure of government spending affects the magnitude of the multiplier, they are still well above unity for contractionary times. 
Building on New Consensus Macroeconomics New Keynesians have recently highlighted that the ability of central banks to stabilise the economy is severely impaired once the economy hits the ZLB, i.e. when inflation gets close to zero and interest rates are low. This argument would suggest that government spending multipliers will be larger at ZLB compared to normal times. Table 4 thus also presents results for several versions of ZLB. Specifications 1 and 2 investigate spending nonlinearity for the periods where inflation rate is less than $1 \%$ and $2 \%$ respectively and Specification 3 investigates the same for the periods where the nominal short-term interest rate falls below $1 \%$. In these specifications the relevant coefficients are not statistically insignificant for the impact of ZLB on GDP growth. Except for specification 2 there is little evidence that multipliers would be higher in ZLB periods.

Table 4 about here

\section{Conclusion}

The size of the multiplier is crucial for formulation of fiscal policy. Several recent contributions have highlighted that multipliers may differ during booms and downswings. This paper has estimated government spending multipliers that differ in the upswing (expansion) and downswing (contraction) period of the business cycle. The model was estimated in panel for 21 OECD countries for the period 1979-2011, controlling for standard growth theory variables such as a catching up term, population growth, export shocks, and inflation as well as for the degree of private sector debt and the short-term real interest rate. The results are to be interpreted as short-run multipliers. We find that the size of multiplier does indeed differ substantially in the different phases of the business cycles. While multipliers are close to one in the upswing, they are substantially higher, around 3 in the 
downswing. Our results also indicate that results are not driven by episodes where monetary policy being constrained by the zero lower inflation bound (as for example argued by De Long and Summers 2012). Overall our results suggest that fiscal policy is a potent tool for countercyclical economic policies.

\section{References}

Acconcia, A., Corsetti, G. and Simonelli, S. (2011) 'Mafia and public spending: evidence on the fiscal multiplier from a quasi-experiment', CEPR Discussion paper No. 8305

Afonso, A, Gruner, H, \& Kolerus, C 2010, 'Fiscal policy and growth: do financial crises make a difference?', ECB Working Paper No. 1217

Afonso, A. and Alegre, J. G. (2011) 'Economic growth and budgetary components: a panel assessment for the EU', Empirical Economics, 41 (3), pp. 703-723.

Afonso, A. and Furceri, D. (2010) 'Government size, composition, volatility and economic growth', European Journal of Political Economy, 26 (4), pp. 517-532.

Afonso, A. And Jalles, J. (2013) 'The cyclicality of education, health, and social security government spending', Applied Economics Letters, Taylor and Francis Journals, 20 (7) pp. 669-672

Antonio, A. and Ricardo, M. S. (2012) 'The macroeconomic effects of fiscal policy', Applied Economics, 44 (3436), pp. 4439-4454.

Arellano, M. and Bond, S. (1991) 'Tests of specification for panel data: Monte Carlo evidence and an application to employment equations', The Review of Economic Studies, 85 (2), pp. 277-297

Auerbach, A, and Gorodnichenko, Y., (2012) 'Fiscal Multipliers in Recession and Expansion', in Fiscal Policy after the Financial Crisis, edited by Alberto Alesina and Francesco Giavazzi (Chicago: University of Chicago Press).

Balli, H. and Sorensen, B. (2013) 'Interaction effects in econometrics', Empirical Economics, 45, pp.583-603

Baltagi, B. (2005) Econometric analysis of panel data. $3^{\text {rd }}$ edn. England: John Wiley \& Sons Ltd.

Barro, R (1989a) 'The Ricardian approach to budget deficit', The Journal of Economic Perspectives, 3 (2), pp. $37-54$

Barro, R. (1989b) 'New Classicals and Keynesians, or the Good Guys and the Bad Guys', NBER Working Papers 2982, National Bureau of Economic Research, Inc.

Bass, F. (1975) 'Pooling issues and methods in regression analysis with examples in marketing research', Journal of Marketing Research, 12 (4), pp. 414-425

Bernanke, B. S., Gertler, M. and Gilchrist, S.(1999) 'The financial accelerator in a quantitative business cycle framework', in Taylor, J. B. \& Woodford, M. (eds.) Handbook of macroeconomics. The US: Elsevier Science B.V, pp. 1342-1390

Blanchard, O. and Perotti, R. (2002) 'An empirical characterization of the dynamic effects of changes in government spending and taxes on output', The Quarterly Journal of Economics, 117 (4), pp. 13291368.

Blanchard, Olivier, Leigh, Daniel, 2013. Growth Forecast Errors and Fiscal Multipliers. International Monetary Fund Working Paper WP13/1

Blyth, M,. 2013. Austerity: The History of a Dangerous Idea. Oxford University Press

Bouakez, H., F. Chihi and Normandin, M. (2010). Measuring the effects of fiscal policy. Centre Interuniversitaire sur le Risque, les Politiques Économiques et l'Emploi, Working Paper 10-16.

Bouthevillain. C. et al (2009): Pros and cons of various fiscal measures to stimulate the economy, Banque Central de Luxembourg Working Paper 40

Brender, A. and Drazen, A. (2004) 'Political budget cycle in new versus established democracies', NBER Working Paper No. 10539

Burnside, C. Eichenbaum, M., and Fisher, J. (2004). 'Fiscal shocks and their consequences.' Journal of Economic theory, 115 (1), pp.89-117.

Burriel, P., de Castro, F., Garrote, D., Gordo, E., Paredes, J. and Perez, J. J. (2010) 'Fiscal policy shocks in the euro area and the US: an empirical assessment', Fiscal Studies, 31 (2), pp. 251-285. 
Caldara, D. and Kamps, C. (2008) "What are the effects of fiscal policy shocks? A VAR-based comparative analysis," Working Paper Series 0877, European Central Bank.

Christiano, L, Eichenbaum, M, \& Rebelo, S (2011), 'When Is the Government Spending Multiplier Large?', Journal Of Political Economy, 119 (1), pp. 78-121

Croux, C., Dhaene, G. and Hoorelbeke, D. (2003) 'Robust standard errors for robust estimators', CESDiscussion paper series 0316

De Cos, P. and Moral-Benito, E. (2013), 'Fiscal Multipliers in Turbulent Times: The Case of Spain', Banco de Espana Working Paper No. 1309.

DeLong, B, Summers, L, 2012. Fiscal policy in a depressed economy. Brookings Papers on Economic Activity, 44, 1:33-297

Eggertson, G, Krugman, P, 2012. Debt, deleveraging, and the liquidity trap: a Fisher-Minsky-Koo approach. Quarterly Journal of Economics (2012) 127 (3): 1469-1513

Fatas, A. and Mihov, I. (2001) The effects of fiscal policy on consumption and employment: theory and evidence. CEPR Discussion Paper No. 2760 London: Center for Economic Policy Research.

Forni, L., Monteforte, L. and Sessa, L. (2009) 'The general equilibrium effects of fiscal policy: estimates for the Euro Area', Journal of Public Economics, 93, pp. 559-585

Friedman, M. (1968) 'The role of monetary policy' The American Economic Review, 58 (1), pp. 1-17

Gali, J. and Perotti, R. (2002). 'Fiscal Policy and Monetary Integration in Europe', CEPR Discussion Papers, Vol. 3933.

Gali, J., Lopez-Salido, J. D. and Valles, J. (2007) 'Understanding the effects of government spending on consumption', Journal of the European Economic Association, 5 (1), pp. 227-270.

Gechert, S. and Will, H. (2012)'Fiscal Multipliers: A Meta Regression Analysis', IMK Working Paper 97-2012, IMK at the Hans Boeckler Foundation, Macroeconomic Policy Institute.

Gechert, S., Mentges, R. (2013). What Drives Fiscal Multipliers? The Role of Private Wealth and Debt, IMK Working Paper 124-2013,

Giavazzi, Fransesco; Pagano, Marco (1990). "Can Severe Fiscal Contractions Be Expansionary? Tales of Two Small European Countries". NBER Macroeconomics Annual 5: 75-111

Greene, W. (2000) Econometric analysis. $4^{\text {th }}$ edn. USA: Prentice Hall

Greenwald, B. and Stiglitz, J. (1987) 'New Keynesian and new classical economics', Oxford Economic Papers, 39 (1), pp. 119-133

Guajardo, Jaime; Leigh, Daniel; Pescatori, Andrea (2011). "Expansionary Austerity: New International Evidence". International Monetary Fund Working Paper WP11/158.

Hebous, S. (2011). The Effects of Discretionary Fiscal Policy on Macroeconomic Aggregates: A Reappraisal. Journal of Economic Surveys 25 (4), 674-707.

Hemming, Richard, Kell, Michael and Mahfouz, Selma (2002): The Effectiveness of Fiscal Policy in Stimulating Economic Activity - A Review of the Literature. IMF Working Paper 02/208

Hicks, J. (1937) 'Mr. Keynes and the "Classics"; A Suggested Interpretation', Econometrica, 5 (1), pp.147-159

Ilzetzki, E. and Vegh, C. A. (2008) 'Procyclical fiscal policy in developing countries: truth or fiction?' NBER Working Paper No. 14191

Ilzetzki, E., Mendoza, E. G. and Vegh, C. A. (2013) 'How big (small?) are fiscal multipliers?', Journal of Monetary Economics, 60 (2), pp. 239-254.

Islam, I. (2013) The rise and fall of fiscal austerity doctrine. Available at: http://www.socialeurope.eu/2013/06/the-rise-and-fall-of-the-fiscal-austerity-doctrine/ (Accessed: 23 September 2013)

Keynes, J, M. (1937) 'The general theory of employment', The Quarterly Journal of Economics, 51 (2), pp.209223

Keynes, J. (1936) The general theory of employment, interest and money. London: Macmillan

Khatiwada, S. (2009) 'Stimulus package to counter global economic crisis: a review', International Institute for Labour Studies Discussion Paper No. DP/196/2009

Kiviet J, 1995. On bias, inconsistency, and efficiency of various estimators in dynamic panel data models. Journal of Econometrics 68 (1995) 53-78

Kraay, A. (2012) 'Government spending multipliers in developing countries: evidence from lending by official creditors', World Bank Working Paper No. 6099

Laeven, L. and Valencia, F. (2008). "Systemic Banking Crises: A New Database”, IMF Working Paper 08/224.

Leeper, E.M.. Walker, T.B. and Yang, S.S. (2008). 'Fiscal foresight: analytics and econometrics'. NBER Working Paper Series No. 14028.

Laidler, D. (1986) 'The new-classical contribution to macroeconomics', Banca Nazionale Del Lavaoro Quarterly Review (1986), 39 (156) pp.27-55

Mankiw, G. (2000) 'The savers-spenders theory of fiscal policy', NBER Working Paper No. 7571

Michaillat, P. (2012) 'Fiscal multipliers over the business cycle', Centre for Economic Performance, LSE, CEP Discussion Papers No. No. 8610 
Miller, J. P. (1982) 'Fiscal policy in monetarist model', Staff Report No. 67, Federal Reserve Bank of Minneapolis

Modigliani, F. (1944) 'Liquidity Preference and Theory of Interest Money', Econometrica, 12 (1) pp. 45-88

Parker, J. 2011. On measuring the effects of sical policy in recessions. NBER working paper 17240

Perotti, R. (2005) Estimating the effects of fiscal policy in OECD countries. CEPR Discussion Paper No. 4842 London: Center for Economic Policy Research.

Ramey, V. A. and Shapiro, M. D. (1999) Costly capital reallocation and the effects of government spending. NBER Working Papers No 6283. National Bureau of Economic Research, Inc.

Ramey, V. A., (2011) 'Identifying government spending shocks: it's all in the timing', Quarterly Journal of Economics, 126 (1), pp.1-50.

Ramey, Valerie. 2011. "Can Government Purchases Stimulate the Economy?” Journal of Economic Literature 49, no. 3: 673-85

Ratto, M., Roeger, W. and Veld, J. (2009) 'QUEST III: An estimated open-economy DSGE model of the euro area with fiscal and monetary policy', Economic Modelling, 26 (1), pp. 222-233.

Reinhart, C. M. and Rogoff, K. S. (2010) 'From financial crisis to debt crisis', NBER Working Paper No. 15795

Roodman, D (2006). "How to Do xtabond2: An Introduction to 'Difference' and 'System' GMM in Stata", Center for Global Development, Working Paper 103

Snowdown, B. and Vane, H. R. (2005) Modern macroeconomics: its origin, development and current state. Cheltenham: Edward Elgar

Spilimbergo, A., S. Symansky, and M. Schindler (2009). Fiscal Multipliers. IMF Staff Position Note SPN/09/11.

Spilimbergo, A., Symansky, S., Blanchard, O. and Cottarelli, C. (2008). "Fiscal Policy for the Crisis", IMF Staff Position Note SPN/08/01.

Stock, H. and Yogo, M. (2002) 'Testing for weak instruments in linear IV regression', NBER Technical Working Paper No. 0284

Staiger, D. and Stock, H. (1997) 'Instrumental variable regression with weak instruments', Econometrica, 65, pp.557-586.

Tagkalakis, A. (2008) 'The effects of fiscal policy on consumption in recessions and expansions', Journal of Public Economics, 92, pp. 1486-1508.

Thomakos, D. (2012) 'Fiscal multipliers in deep economic recessions and the case for a 2-year extension in Greece's austerity programme', Eurobank EFG Economic Research, 8 (4), pp. 1-44

Turrini, A., Roeger, W. and Szekely, I. P. (2012) 'Banking crisis, output loss, and fiscal policy', CESifo Economic Studies, 58 (1), pp. 181-219.

Woodford, M. (2009) 'Convergence in macroeconomics: elements of new synthesis', American Economic Journal, 1 (1), pp. $267-279$

Wooldridge, M. (2002) Econometric analysis of cross section and panel data. London: The MIT Press 
Table 1 Summary of Empirical Literature Investigating the Impact of Government Spending on Output

\begin{tabular}{|c|c|c|c|c|c|}
\hline No. & Authors & $\begin{array}{l}\text { Econometric } \\
\text { Methodology }\end{array}$ & $\begin{array}{l}\text { Linearity/Non- } \\
\text { linearity }\end{array}$ & Sample & Results \\
\hline 1 & Blanchard and Perotti (2002) & SVAR & Linearity & QD, USA, $1960-1997$ & Spending Multiplier $=0.9$ to 1.29 \\
\hline 2 & Fatah and Mihov (2001) & RVAR & Linearity & QD, USA, $1960-1996$ & Spending Multiplier $=0.7-1.74$ \\
\hline 3 & Perotti (2005) & SVAR & Linearity & $\begin{array}{l}\text { QD, USA, West Germany, the UK, } \\
\text { Canada and Australia, 1960-2001 }\end{array}$ & $\begin{array}{l}\text { Spending Mutiplier }=1.29-1.4 \text { for the US in pre-1980s. } \\
\text { Spending Multiplier }=0.36-0.28 \text { for the US in post-1980s }\end{array}$ \\
\hline 4 & Gali et. al. (2007) & SVAR & Linearity & QD, USA, 1948 to 2003 & Spending Multiplier $=0.78$ to 1.74 \\
\hline 5 & Burriel et al. (2010) & SVAR & Linearity & QD, EMU, US,1981-2007 & Spending Multiplier $=0.87-0.85$ for EMU \\
\hline 6 & Ramey and Shapiro (1999) & EVAR & Linearity & QD, USA, 1947-1996 & $\begin{array}{l}\text { Negative response of private consumption to government } \\
\text { spending shock, but they showed that output rises for three } \\
\text { quarters }\end{array}$ \\
\hline 7 & Burnside et al (2004) & EVAR & Linearity & QD, US, 1947-1995 & $\begin{array}{l}\text { Output rises and there is small movement in private } \\
\text { consumption and investment }\end{array}$ \\
\hline 8 & Ilzetzki et al. (2013) & RVAR & Linearity & QD, 44 Countries, 1960-2007 & $\begin{array}{l}\text { Government consumption multiplier }=0.66 \text { for high income } \\
\text { countries and }-0.63 \text { for low income countries. Government } \\
\text { Investment multiplier }=1.5 \text { for high income and } 1.6 \text { for low } \\
\text { income countries. Multipliers depend on crucial } \\
\text { charactersitics of economies. }\end{array}$ \\
\hline 9 & Mountford and Uhlig (2008) & $\mathrm{MH}-\mathrm{VAR}$ & Linearity & QD, US, 1955-2000 & $\begin{array}{l}\text { Spending Multiplier }=0.65 \text { to }-0.97 \\
\text { Government spending shock increases output, but the } \\
\text { response of private consumption is small and only } \\
\text { significantly different from zero on impact }\end{array}$ \\
\hline & Forni et al. (2009) & NK - DSGE & Linearity & QD, EA, 1980-2005 & $\begin{array}{l}\text { The biggest impact of government spending component } \\
\text { was shown from transfer to households, accounting for one } \\
\text { to one increase in disposable income of non- Ricardian } \\
\text { consumers. }\end{array}$ \\
\hline & Afonso and Ricardo (2012) & NK - DSGE & Linearity & $\begin{array}{l}\text { QD, USA, UK, Germany, Italy, } 1964 \\
\text { to } 2007\end{array}$ & $\begin{array}{l}\text { Government spending have insignificant impact on private } \\
\text { consumption and crowds - out private investment. }\end{array}$ \\
\hline & Ratto et al. (2009) & NK - DSGE & Linearity & QD, EA, 1981-2006. & Spending Multiplier $=0.73$ to 0.45 \\
\hline 13 & Afonso and Fuceri (2010) & CCOLS & Linearity & $\begin{array}{l}\mathrm{AD}, 15 \mathrm{EU} \text { and remaining OECD, } \\
1970-2004\end{array}$ & Government spending having detrimental effecton growth \\
\hline 14 & Afonso and Alegre (2011) & GMM & Linearity & $\mathrm{AD}<15 \mathrm{EU}, 1971-2006$ & $\begin{array}{l}\text { Negative impact of government consumption, but positive } \\
\text { impact of government investment and budget deficit. }\end{array}$ \\
\hline
\end{tabular}




\begin{tabular}{clllll}
15 & Acconcia et al. (2011) & PLTSL & Linearity & AD, Italy, 1990-1999 & Spending multiplier $=1.2-1.4$ \\
\hline 16 & Christiano et al. (2011) & CNK-DSGE & Nonlinearity & QD, US, 2000-2010 & $\begin{array}{l}\text { Spending Multiplier =1.6-2.3 when zero-bound binding and } \\
\text { less than unity when nominal interest rate follows Taylor } \\
\text { rule }\end{array}$ \\
\hline 17 & $\begin{array}{l}\text { Auerbach and Gorodnichenko } \\
(2012)\end{array}$ & RSVAR & Nonlinearity & QD, OECD,1985-2010 & $\begin{array}{l}\text { Spending Multiplier }=2.3 \text { in recession and almost 0 in } \\
\text { normal times (for the USA) }\end{array}$ \\
\hline 18 & De Cos and Moral-Benito (2013) & RSVAR & Nonlinearity & QD, Spain, 1986-2012 & $\begin{array}{l}\text { Spending multiplier }=1.4 \text { in recession and 0.6 in normal } \\
\text { times }\end{array}$ \\
\hline 19 & Thomakos (2012) & RSVAR & Nonlinearity & QD, Greece, 2000-2012 & $\begin{array}{l}\text { Spending mutiplier }=1.32 \text { during recession and near zero in } \\
\text { normal times. }\end{array}$ \\
\hline 20 & Turini et al (2012) & PLTSL & Nonlinearity & AD, 56 Countries, 1970-2008 & $\begin{array}{l}\text { Spending Multiplier }=0.8 \text { during crisis and 0.2 during } \\
\text { normal times }\end{array}$ \\
\hline 21 & Afonso et al. (2010) & PLTSL & Nonlinearity & AD, 98 Countries,1981-2007 & $\begin{array}{l}\text { Regular Spending multiplier }=0.6 \text { to 1.1. Multipliers } \\
\text { during recession and normal times not statistically different } \\
\text { from each other }\end{array}$
\end{tabular}

Note: The papers from 1 to 15 , do not investigate the non-linearity in government spending. From 16 to 21 , the papers investigate the multiplier during normal times and crisis. Details of abbreviations used are as following:

SVAR = Structural VAR, RVAR=Recursive VAR, MH VAR = The Mountford and Uhlig VAR, EVAR=Event Study VAR, NK-DSGE= New Keynesian Dynamic

Stochastic General Equilibrium Model Caliberated, RSVAR=Regime Switching SVAR CCOLS=Cross-country OLS, PLTSL=Panel Two-Stage Least Square,

$\mathrm{GMM}=$ Generalized Methods of Moment, QD=Quarterly Data, AD=Annual Data, EMU=European Monetary Union, EA=European Area, EU=European Union,

DC=Developing Countries 
Table 2. GDP Growth Rate as Dependent Variable, GFC Interacted with Contraction Dummy- 21 Cross Sections

\begin{tabular}{|c|c|c|c|c|c|}
\hline & $\begin{array}{c}\text { (1) } \\
\text { Pooled TSLS }\end{array}$ & $\begin{array}{c}(2) \\
\text { Pooled TSLS }\end{array}$ & $\begin{array}{c}\text { (3) } \\
\text { FE TSLS }\end{array}$ & $\begin{array}{l}\text { (4) } \\
\text { FE }\end{array}$ & $\begin{array}{c}(5) \\
\text { Pooled } \\
\text { OLS }\end{array}$ \\
\hline Const & $\begin{array}{l}0.018 * * * \\
(0.003)\end{array}$ & $\begin{array}{c}0.027 * * * \\
(0.005)\end{array}$ & $\begin{array}{l}0.014 \\
(0.015)\end{array}$ & $\begin{array}{l}0.023 * * \\
(0.011)\end{array}$ & $\begin{array}{l}0.028 * * * \\
(0.004)\end{array}$ \\
\hline $\operatorname{GDP}(-1)$ & $\begin{array}{l}0.398 * * * \\
(0.092)\end{array}$ & $\begin{array}{c}0.353 * * * \\
(0.105)\end{array}$ & $\begin{array}{c}0.267 * * * \\
(0.082)\end{array}$ & $\begin{array}{c}0.403 * * * \\
(0.052)\end{array}$ & $\begin{array}{l}0.476 * * * \\
(0.055)\end{array}$ \\
\hline Pop(-1) & $\begin{array}{l}-0.588 * * * \\
(0.002)\end{array}$ & $\begin{array}{l}-0.24 \\
(0.002)\end{array}$ & $\begin{array}{l}-0.881 * * * \\
(0.003)\end{array}$ & $\begin{array}{c}-0.600 * * * \\
(0.002)\end{array}$ & $\begin{array}{l}-0.086 \\
(0.002)\end{array}$ \\
\hline Cat(-1) & $\begin{array}{l}0.180 \\
(0.003)\end{array}$ & $\begin{array}{l}0.590 * * * \\
(0.003)\end{array}$ & $\begin{array}{l}11.200 \\
(0.080)\end{array}$ & $\begin{array}{l}14.1 * * * \\
(0.043)\end{array}$ & $\begin{array}{l}0.689 * * * \\
(0.003)\end{array}$ \\
\hline XShock(-1) & & $\begin{array}{l}0.38 \\
(0.003)\end{array}$ & $\begin{array}{l}0.974 \\
(0.008)\end{array}$ & $\begin{array}{l}0.38 \\
(0.005)\end{array}$ & $\begin{array}{l}0.445 \\
(0.003)\end{array}$ \\
\hline Inf & & $\begin{array}{l}-0.07 * * * \\
(0.000)\end{array}$ & $\begin{array}{l}-0.083 * * * \\
(0.000)\end{array}$ & $\begin{array}{l}-0.100 * * * \\
(0.000)\end{array}$ & $\begin{array}{l}-0.067 * * * \\
(0.000)\end{array}$ \\
\hline $\mathrm{DCP}(-1)$ & & $\begin{array}{l}-0.01 * * * \\
(0.000)\end{array}$ & $\begin{array}{l}-0.012 * * * \\
(0.000)\end{array}$ & $\begin{array}{l}-0.015 * * \\
(0.000)\end{array}$ & $\begin{array}{l}-0.01 * * * \\
(0.000)\end{array}$ \\
\hline $\mathrm{R}(-1)$ & & $\begin{array}{l}-0.07 * * \\
(0.000)\end{array}$ & $\begin{array}{l}-0.097 * * * \\
(0.000)\end{array}$ & $\begin{array}{l}-0.112 * * * \\
(0.000)\end{array}$ & $\begin{array}{l}-0.073 * * \\
(0.000)\end{array}$ \\
\hline Cont & $\begin{array}{l}-0.024 * * * \\
(0.004)\end{array}$ & $\begin{array}{c}-0.026^{* * *} \\
(0.004)\end{array}$ & $\begin{array}{c}-0.024 * * * \\
(0.003)\end{array}$ & $\begin{array}{l}-0.022 * * * \\
(0.002)\end{array}$ & $\begin{array}{c}-0.022 * * * \\
(0.002)\end{array}$ \\
\hline GFC $*$ Cont & $\begin{array}{l}0.533 * * \\
(0.243)\end{array}$ & $\begin{array}{l}0.661 * * * \\
(0.250)\end{array}$ & $\begin{array}{l}0.682 * * * \\
(0.217)\end{array}$ & $\begin{array}{l}0.219 * * * \\
(0.045)\end{array}$ & $\begin{array}{l}0.227 * * * \\
(0.034)\end{array}$ \\
\hline $\mathrm{GFC}^{*}$ (1-Cont) & $\begin{array}{l}0.204 \\
(0.165)\end{array}$ & $\begin{array}{l}0.218 \\
(0.192)\end{array}$ & $\begin{array}{l}0.332 \\
(0.227)\end{array}$ & $\begin{array}{l}-0.007 \\
(0.052)\end{array}$ & $\begin{array}{l}0.02 \\
(0.051)\end{array}$ \\
\hline $\begin{array}{l}\mathrm{N} \\
\text { Adj. } \mathrm{R}^{2}\end{array}$ & $\begin{array}{l}591 \\
0.371\end{array}$ & $\begin{array}{l}550 \\
0.391\end{array}$ & $\begin{array}{l}550.00 \\
0.38\end{array}$ & $\begin{array}{l}550 \\
0.477\end{array}$ & $\begin{array}{l}550 \\
0.452\end{array}$ \\
\hline $\begin{array}{l}\text { First Stage F- } \\
\text { Statistics }\end{array}$ & 31.3 & 28.6 & 8.7 & & \\
\hline $\begin{array}{l}\text { Test Statistics for } \\
\text { Common Group } \\
\text { Intercept }\end{array}$ & & & $1.90 * *$ & & \\
\hline $\begin{array}{l}\text { Contraction } \\
\text { Multiplier }\end{array}$ & 2.48 & 3.07 & 3.17 & 1.02 & 1.06 \\
\hline $\begin{array}{l}\text { Expansion } \\
\text { Multiplier }\end{array}$ & 0.95 & 1.01 & 1.54 & -0.03 & 0.09 \\
\hline
\end{tabular}

Note: $* * *, * *$, and $*$ denotes less than $1 \%, 5 \%$, and $10 \%$ statistical significance respectively.

Standard errors are HAC robust and reported in parentheses. GFC and GDP are in growth rate. 
Table 3. GDP Growth Rate as Dependent Variable, GTE Interacted with Contraction Dummy- 21 Cross Sections
(1)
(2)
(3)
(4)

Pooled TSLS FE TSLS

FE

Pooled OLS

\begin{tabular}{lllll}
\hline Const & $0.028^{* * *}$ & 0.021 & $0.025^{* *}$ & $0.027^{* * *}$ \\
& $(0.005)$ & $(0.015)$ & $(0.012)$ & $(0.004)$ \\
\hline GDP(-1) & $0.361^{* * *}$ & $0.281^{* * *}$ & $0.357^{* * *}$ & $0.437^{* * *}$ \\
& $(0.094)$ & $(0.082)$ & $(0.047)$ & $(0.052)$ \\
\hline POP (-1) & -0.134 & $-0.972^{* * * *}$ & $-0.76^{* * *}$ & -0.055 \\
& $(0.003)$ & $(0.003)$ & $(0.002)$ & $(0.002)$ \\
\hline Cat(-1) & $0.526^{*}$ & 10.850 & $12.419^{* * *}$ & $0.627^{* *}$ \\
& $(0.003)$ & $(0.077)$ & $(0.038)$ & $(0.003)$ \\
\hline Xshock(-1) & 0.335 & 0.567 & 0.153 & 0.372 \\
& $(0.003)$ & $(0.010)$ & $(0.008)$ & $(0.003)$ \\
\hline Inf & $-0.051^{* *}$ & $-0.050^{*}$ & $-0.061^{* * *}$ & $-0.057^{* * *}$ \\
& $(0.000)$ & $(0.000)$ & $(0.000)$ & $(0.000)$ \\
\hline DCP(-1) & $-0.009^{* * *}$ & $-0.012^{* * *}$ & $-0.014^{* * *}$ & $-0.009^{* * *}$ \\
& $(0.000)$ & $(0.001)$ & $(0.000)$ & $(0.000)$ \\
\hline R(-1) & $-0.067^{* *}$ & $-0.097^{* * *}$ & $-0.104^{* * *}$ & $-0.069^{* *}$ \\
\hline Cont & $(0.000)$ & $(0.000)$ & $(0.000)$ & $(0.000)$ \\
& $-0.024^{* * *}$ & $-0.021^{* * *}$ & $-0.019^{* * *}$ & $-0.019^{* * *}$ \\
\hline GTE*Cont & $(0.003)$ & $(0.003)$ & $(0.002)$ & $(0.002)$ \\
& $0.477^{* * *}$ & $0.448^{* * *}$ & $0.199^{* * *}$ & $0.198^{* * *}$ \\
\hline GTE*(1-Cont) & $(0.146)$ & $(0.145)$ & $(0.054)$ & $(0.043)$ \\
& 0.117 & 0.172 & $0.088^{* * *}$ & $0.094^{* * *}$ \\
\hline N & $(0.153)$ & $(0.181)$ & $(0.033)$ & $(0.029)$ \\
Adj. R ${ }^{2}$ & 506 & 506 & 513 & 513 \\
\hline First Stage F-Statistics & 0.416 & 0.431 & 0.480 & 0.454 \\
\hline Common Group Intercept & 28.681 & 7.780 & & \\
\hline Recession Multiplier & & $2.1^{* * *}$ & $2.281^{* * *}$ & \\
Normal Times Multiplier & 1.975 & 1.855 & 0.824 & 0.820 \\
\hline Not *,$* .485$ & 0.712 & 0.364 & 0.389 \\
\hline
\end{tabular}

Note: $* * *, * *$, and $*$ denotes less than $1 \%, 5 \%$, and $10 \%$ statistical significance respectively. Standard errors are HAC robust and reported in parentheses. TE and GDP are in growth rate. 
Table 4. Estimations for Interaction of Government Spending with Nominal Lower Zero Bound

Pooled TSLS Estimation for GFC: GDP Growth Rate as Dependent Variable - 21 Cross Sections

(1)

(2)

(3)

ZLB1 = Inflation $<=2 \% \quad$ ZLB2 $=$ Inflation $<=1 \%$

ZLB3=Nom Interest

Rate $<=1 \%$

\begin{tabular}{llllll}
\hline ZLB1 & -0.014 & ZLB2 & -0.013 & ZLB3 & -0.0013 \\
& $(7.575)$ & & $(0.010)$ & & $(0.008)$ \\
\hline GFC*ZLB1 & 0.000002 & GFC*ZLB2 & 0.491 & GFC*ZLB3 & -0.288 \\
& $(0.000)$ & & $(0.581)$ & & $(0.630)$ \\
\hline GFC*(1-ZLB1) & -0.000001 & GFC*(1-ZLB2) & 0.269 & GFC*(1-ZLB3) & $0.423 * * *$ \\
& $(0.000)$ & & $(0.177)$ & & $(0.149)$ \\
\hline
\end{tabular}

Pooled TSLS Estimation for GTE: GDP Growth Rate as Dependent Variable - 21

Cross Sections

\begin{tabular}{llllll}
\hline ZLB1 & 0.465041 & ZLB2 & -0.004 & ZLB3 & 0.081 \\
& $(0.031)$ & & $(-0.017)$ & & $(0.153)$ \\
\hline GTE*ZLB1 & -0.00002 & GTE*ZLB2 & 0.0000003 & GTE*ZLB3 & -0.000003 \\
& $(0.000)$ & & $(0.000)$ & & $(0.000)$ \\
\hline GTE*(1-ZLB1) & 0.0001 & GTE*(1-ZLB2) & 0.000002 & GTE*(1-ZLB3) & 0.000003 \\
& $(0.002)$ & & $(0.000)$ & & $(0.000)$ \\
\hline
\end{tabular}

Note: $* * *, * *$, and $*$ denotes statistical significance at less than $10 \%, 5 \%$ and $1 \%$ respectively. Other control variables not reported are constant term, lagged GDP, lagged POP, lagged CAT, lagged INF, and lagged Xshock, lagged DCP and lagged R. Standard errors are HAC robust and reported in parentheses. 


\section{Appendix A1. Data Source and Definition}

\begin{tabular}{|c|c|c|c|}
\hline No. & Variable & Definition & Source \\
\hline 1 & GDP & Real GDP Growth Rate & AMECO \\
\hline 2 & GFC & $\begin{array}{l}\text { Real Final Consumption Expenditure of } \\
\text { General Government, Growth Rate }\end{array}$ & AMECO \\
\hline 3 & GTE & $\begin{array}{l}\text { Total Government Expenditure= GFC+ } \\
\text { Government Investment Expenditure }\end{array}$ & AMECO \\
\hline 3 & Cont & $\begin{array}{l}\text { An interpretation of OECD CLI defining } \\
\text { periods of contraction from the Period } \\
\text { following the Peak through the Trough }\end{array}$ & $\begin{array}{l}\text { Federal Reserve } \\
\text { Bank of St. Louis }\end{array}$ \\
\hline 4 & POP & Population Growth Rate & OECD \\
\hline 5 & CAT & $\begin{array}{l}\text { Catching UP term, PPP GDP of respective } \\
\text { country vis-à-vis US GDP }\end{array}$ & $\begin{array}{l}\text { Federal Reserve } \\
\text { of St. Louis }\end{array}$ \\
\hline 6 & INF & CPI, Inflation Rate \% & AMECO \\
\hline 7 & Xshock & Real Exports Divided by Real Imports & AMECO \\
\hline 8 & DCP & $\begin{array}{l}\text { Domestic Credit to Private Sector as Ratio of } \\
\text { GDP }\end{array}$ & World Bank \\
\hline 9 & NR & Short term Nominal Interest Rate & AMECO \\
\hline 10 & ZLB1 & If inflation $<=2 \%$ & \\
\hline 11 & ZLB2 & If inflation $<=1 \%$ & \\
\hline 12 & ZLB3 & If nominal interest rate $<=1 \%$ & \\
\hline 13 & $\mathrm{R}$ & Short-term Real Interest Rate & AMECO \\
\hline
\end{tabular}

